Original research

\title{
UJI AKTIVITAS ANTIBAKTERI FRAKSI EKSTRAK DAUN MINDI (Melia azedarach L.) TERHADAP PERTUMBUHAN BAKTERI Staphylococcus epidermidis SECARA IN VITRO
}

\section{ANTIBACTERIAL ACTIVITY OF MINDI LEAF EXTRACT (Melia azedarach L.) FRACTION IN THE GROWTH OF Staphylococcus epidermidis IN VITRO}

\author{
Kalaudius Gading ${ }^{1}$, Rabima ${ }^{2}$ \\ ${ }^{1,2}$ Fakultas Farmasi, Universitas 17 Agustus 1945, Jakarta, Indonesia, 14356 \\ *E-mail: kalaudiusgading12@gmail.com
}

Diterima: 09/09/2019

Direvisi: 23/09/2019

Disetujui: 18/10/2019

\begin{abstract}
Abstrak
Jerawat merupakan salah satu penyakit infeksi yang dapat di sebabkan oleh bakteri S. epidermidis.Pada sebagian besar kasus infeksi, penggunaan antibiotik sangat diperlukan tetapi apabila pemakaian atntibiotik berlebihan akan menyebabkan bakteri menjadi resisten. Salah satu tanaman yang memiliki khasiat sebagai antibakteri adalah daun Mindi (Melia azedarach L.).Tujuan dari penelitian ini adalah untuk mengetahui aktivitas antibakteri fraksi daun mindi (Melia azedarach L.) terhadap pertumbuhan bakteri Staphylococcus epidermidis.Metode yang digunakan adalah metode ekstraksi dan metode fraksi dan pengujian pengujian antibakteri dengan mengunkan metode dilusi padat. Penelitian ini menggunakan 4 variasi konsentrasi fraksi yang berbeda yaitu $3000 \mu \mathrm{g} /$ disk, $2500 \mu \mathrm{g} /$ disk, $2000 \mu \mathrm{g} /$ disk dan $1500 \mu \mathrm{g} / \mathrm{disk}$ dengan satu kontrol positif yang berisi klindamisin dan satu kontrol negatif yang berisi DMSO dengan pengulangan percobaan 3 kali. KHM dilakukan dengan metode dilusi cair Kirby and Bauer, penelitian ini menggunakan 4 variasi konsentrasi yaitu 10.000 ppm, 30.000 ppm, 50.000 ppm, dan 70.000 ppm. Media yang digunakan adalah Mueller Hinton Agar (MHA) dan Mueller Hinton Broth(MHB). Masa inkubasi dilakukan selama 1 hari atau 24 jam pada suhu $37^{\circ}$ C.Pengamatan dilakukan dengan melihat pertumbuhan koloni bakteri pada permukaan media. Hasil penelitian menunjukkan bahwa daya hambat yang paling besar terhadap pertumbuhan bakteri Staphylococcus epidermidis. secara berturut-turut adalah adalah Fraksi etil asetat, fraksi air, fraksi n-heksan dan hasil penentuan kadar hambat minimum yaitu pada konsentrasi 50.000 ppm.
\end{abstract}

Kata kunci;Jerawat, Staphylococcus epidermidis, MHA, MHB, Melia azedarach L. 


\begin{abstract}
Acne is one of the infectious diseases that can be caused by Staphylococcus epidermidis bacteria. In most cases of infection, the use of antibiotics is very necessary but if excessive antibiotic use will cause bacteria to become resistant. One of the plants that has antibacterial properties is the leaves of Mindi (Melia azedarach L.). The purpose of this study was to determine the antibacterial activity of mindi leaf fraction (Melia azedarach L.) on the growth of Staphylococcus epidermidis bacteria. The method used is the extraction method and the fraction method and antibacterial testing by using the solid dilution method. This study uses 4 variations of different fraction concentrations, namely $3000 \mu \mathrm{g} / \mathrm{disk}, 2500 \mu \mathrm{g} / \mathrm{disk}, 2000 \mu \mathrm{g} / \mathrm{disk}$ and $1500 \mu \mathrm{g} / \mathrm{disk}$ with one positive control containing clindamycin and one negative control containing DMSO with repeated experiments 3 times. The KHM was carried out by the Kirby and Bauer liquid dilution method, this study used 4 variations of concentration which were $10,000 \mathrm{ppm}, 30,000 \mathrm{ppm}, 50,000 \mathrm{ppm}$ and 70,000 ppm. The media used are Mueller Hinton Agar (MHA) and Mueller Hinton Broth (MHB). The incubation period is carried out for one day or 24 hours at $37^{\circ} \mathrm{C}$. Observations were made by looking at the growth of bacterial colonies on the surface of the media. The results showed that the greatest inhibitory effect on the growth of Staphylococcus epidermidis bacteria, respectively were ethyl acetate fraction, water fraction, $\mathrm{n}$-hexane fraction and the results of determining the minimum inhibitory level at a concentration of 50,000 ppm.
\end{abstract}

Keywords; Acne, Staphylococcus epidermidis, MHA, MHB, Melia azedarach L.

\title{
PENDAHULUAN
}

Jerawat menjadi masalah yang banyak dikhawatirkan oleh kaum muda. Walaupun jerawat bukan sesuatu penyakit yang serius, tetapi jerawat menjadi pertimbangan psikologis karena dapat membuat rasa percaya diri seseorang menjadi menurun[1]. Jerawat itu sendiri merupakan suatu kondisi kulit yang abnormal dikarenakan gangguan produksi dari kelenjar minyak yang berlebihan. Daerah yang mudah terkena jerawat ialah muka, bahu, bagian atas dari ekstremitas superior, dada, dan punggung[2]. Staphylococcus epidermidis yang diketahui dapat menyebabkan infeksi oportunistik[3]. kebanyakan bakteri cocci pada kaki adalah Staphylococcus epidermidis. bakteri ini dapat mendegredasi epidermidis adalah salah satu penyebab terjadinya jerawat pada kulit. bakteri ini merupakan salah satu spesies bakteri dari genus leusin yang dihasilkan keringat, sehingga terbentuk asam isovalerat, asam isovalerat merupakan suatu asam lemak yang dilaporkan sebagai penyebab timbulnya bau kaki[4].Pada sebagian besar kasus infeksi, penggunaan antibiotik sangat diperlukan tetapi apabila pemakaian antibiotik berlebihan akan menyebabkan bakteri menjadi resisten[5].

Tanaman Mindi (Melia azedarach L.) adalah salah satu tanaman berfamili Meliaceae, yang merupakan tanaman asli dari Mexico dan Argentina. Tanaman ini dapat tumbuh di Indonesia yang beriklim tropis[6]. Dalam kehidupan sehari-hari tanaman mindi sering digunakan secara tradisional sebagai obat malaria, diabetes, batuk, penyakit kulit, dan lainlain[7]. Penelitian lain menyatakan bahwa ekstrak daun mindi memiliki aktivitas sebagai antioksidan, antibakteri dan analgesic[8]. Daun mindi terdapat kandungan metabolik sekunder antara lain alkaloid, tannin, saponin, fenolik, glikosida, steroid, terpenoid, dan flavonoid dimana dalam ekstrak daun mindi mengandung senyawa fenolik dalam jumlah yang banyak[9].

Berdasarkan latar belakang tersebut peneliti tertarik untuk melakukan penelitian tentang apakah daun mindi memilliki aktivitas antibakteri secara in vitro. 


\section{METODE}

\section{Sampel (Bahan) Penelitian}

Daun mindi yang diperoleh dari Lembagan Ilmu Pengetahuan Indonesia (LIPI) cibinong, bogor, jawa baratMueller Hinton Agar (MHA), Mueller Hinton Broth (MHB), etanol 70\%, etil asetat(PPR24053), n-heksan(V.030),DMSO (K48550752) bakteri Staphylococcus epidermidis (atcc 7969), klindamisin (6mm), Aquadest.

\section{Prosedur kerja}

\section{Ekstraksi Daun Mindi dengan Etanol 70\%}

Ekstraksi Daun Mindi dilakukan dengan cara maserasi. Daun Mindi yang telah menjadi serbuk halus sebanyak 1,5 kilogram dengan 3 liter etanol $70 \%$ selama 3 hari (3x 24 jam). Setiap1 x 24 jam rendaman simplisia daun mindi disaring dengan menggunakan kertas saring. Filtrat yang ditampung, kemudian disatukan dan dipekatkan dengan menggunakanrotary evaporator pada suhu $40^{\circ} \mathrm{C}$, sehingga diperoleh ektrak agak kental, kemudian ekstrak tersebut dipindahkan ke cawan penguap untuk dilanjutkan pemekatannya di atas water bath sehingga didapatkan ekstrak kental dari daun mindi[10].

\section{Skrining Fitokimia}

Mengidentifikasi senyawa aktif, yang terkandung dalam ekstrak Daun Mindi (Melia azedarach $L$ ). Uji skrining fitokimia yang dilakukan hanya pada uji alkaloid, tanin, flavonoid, saponin, steroid dan terpenoid sebagai berikut:

\section{Identifikasi Golongan Alkaloid}

Sampel masing-masing sebanyak $2 \mathrm{~mL}$ ditambahkan $5 \mathrm{~mL}$ kloroform dan 5 mLamoniak kemudian dipanaskan, dikocok dan disaring. Ditambahkan 5tetes asam sulfat, kocok, didiamkan. Bagian atas dari masing-masing filtrat diambil dan diuji denganpereaksi Mayer terbenntuk endapan putih, endapan cokelat pada pereaksi Wagner, danendapan orange atau jingga pada pereaksi Dragendroff [11].

\section{Identifikasi Tanin}

Sampel 1-2 tetes ditambahkan $\mathrm{FeCl}_{3} 1 \%$ 3, amati perubahan warna yang terjadi. Adanya senyawa tanin ditandai dengan terbentuknya warna biru kehijauan atau hijau tua[11].

\section{Identifikasi Flavonoid}

Sampel sebanyak 0,5 g ditambahkan $20 \mathrm{~mL}$ air panas, didihkan selama 5 menit, disaring. Filtrat sebanyak $5 \mathrm{~mL}$ ditambahkan $0,05 \mathrm{~g}$ serbuk dan $1 \mathrm{~mL} \mathrm{HCl}$ pekat, kocok. Positif mengandung flavonoid ditunjukkan dengan terbentuknya warna merah, kuning atau jingga[12].

\section{Identifikasi Steroid/Triterpenoid}

Sampel 1-2 tetes ditambahkan asam asetat glasial 10 tetes dan $\mathrm{H}_{2} \mathrm{SO}_{4}$ pekat 2 tetes. dikocokdan dibiarkan selama beberapa menit. Positif mengandung steroid apabila terbentuk warna biru atau hijau, sedangkan triterpenoid terbentuk warna merah atau ungu[12]. 


\section{Identifikasi golongan Saponin}

Sampel 0,5 g ditambahkan $10 \mathrm{~mL}$ air panas, dinginkan, setelah dingin langsung dikocok kuat selama 10 detik, jika terbentuk buih yang stabil selama 10 menit setinggi $1-10 \mathrm{~cm}$ dan setelah ditambahkan 1 tetes $\mathrm{HCl} 2 \mathrm{~N}$ buihnya tidak hilang, maka menunjukkan adanya senyawa saponin[11].

\section{Fraksinasi}

Ekstrak etanol kental daun mindi ditimbang sebanyak 30 gram, lalu dilarutkan dengan 90 $\mathrm{mL}$ air, lalu ditambah $90 \mathrm{~mL}$ n-heksan, aduk dan masukkan kedalam corong pemisah, kocok dan diamkan sampai terbentuk dua lapisan. Diperoleh fraksi air dan fraksi n-heksan. Fraksi n-heksan dipisahkan, fraksi air difraksinasi kembali dengan etil asetat sebanyak $90 \mathrm{ml}$, aduk dan masukkan kedalam corong pemisah, kocok dan diamkan sampai diperoleh dua lapisan. Pisahkan fraksi air dan fraksi etil asetat. Masing-masing fraksi yang telah ditampung kemudian dipekatkan dengan menggunakan rotary evaporato[13].

\section{Pembiakan Bakteri Uji Staphylococcus epidermidis}

Pembuatan stok bakteri ini dilakukan untuk memperbanyak dan meremajakan bakteri, dengan cara menginokulasikan 1 ose biakan murni Staphylococus epidermidis kedalam 1 tabung reaksi yang berisi media Mueller Hinton Agar (MHA), lalu diinkubasikan pada suhu $37^{\circ} \mathrm{C}$ selama 24 jam didalam inkubator. Kemudian biakan bakteri uji disuspensikan ke dalam larutan $\mathrm{NaCl}$ fisiologis $0,9 \%$. Kekeruhan bakteri ditentukan dengan menggunakan standar Mc. Farland 0,5 [15].

\section{Pembuatan Larutan Pengenceran Uji Aktivitas Dari Masing-masing Fraksi}

Masing-masing fraksi ditimbang sebanyak $600 \mathrm{mg}$ dilarutkan dalam $1 \mathrm{~mL}$ larutan DMSO. Kemudian dibuat variasi konsentrasi $3000 \mu \mathrm{g} / 20 \mu \mathrm{L}, 2500 \mu \mathrm{g} / 20 \mu \mathrm{L}, 2000 \mu \mathrm{g} / 20 \mu \mathrm{L}, 1500$ $\mu \mathrm{g} / 20 \mu \mathrm{L}$.

\section{Pewarnaan Gram Bakteri}

Suspensi bakteri diambil sebanyak 1-2 ose, diletakkan diatas kaca objek, difiksasi, Teteskan 1 tetes larutan karbol kristal violet, cuci dengan air suling. Teteskan larutan lugol biarkan,cuci dan bilas dengan etanol 95\% selama 30 detik,cuci dengan air, teteskan larutan fuchsin, biarkan mengering, cuci dengan air dan keringkan, teteskan minyal Oil immersion diatas preparat, amati menggunakan mikroskop[15].

\section{Uji Aktivitas Antibakteri}

Suspensi bakteri Staphylococcus epidermidis sebanyak $5 \mathrm{ml}$ dimasukan ke dalam plate lalu tambah media Mueller Hinton Agar (MHA) sebanyak $20 \mathrm{ml}$, homogenkan dan biarkan membeku. Cakram uji kosong direndam dengan masing-masing konsentrasi fraksi sebanyak $20 \mu 1$ dengan menggunakan makropipet. Untuk kontrol negatif dengan larutan DMSO dan kontrol positif dengan antibiotik klindamisin. kemudian diletakkan di atas Mueller Hinton Agar (MHA) secara steril. Lalu diinkubasi ke dalam inkubator pada $37^{\circ} \mathrm{C}$ dan amati zona terang yang terbentuk[16]. 


\section{Penentuan Kadar Hambat Minimum (KHM)}

Penentuan KHM dilakukan dengan metode dilusi cair Kirby and Bauer menggunakan media cair Mueller Hinton Broth(MHB) dan diukur absorbansi dengan spektrofotometer UVVis sebelum dan sesudah inkubasi untuk melihat pertumbuhan bakteri uji.Sebanyak $5 \mathrm{ml}$ media MHB steril ditambahkan $5 \mu \mathrm{L}$ suspensi bakteri dimasukan ke dalam masing-masing tabung reaksi dan ditambahkan ekstrak dengan konsentrasi 10.000 ppm, 30.000 ppm, 50.000 ppm, 70.000 ppm. Tabung reaksi tersebut kemudian diukur absorbansi (Optical Density bakteri dengan menggunakan spektrofotometer UV-Vis $(\lambda=600 \mathrm{~nm})$ selanjutnya tabungtabung tersebut diinkubasi selama $18-24$ jam pada suhu $37^{\circ} \mathrm{C}$ dalam inkubator. Setelah diinkubasi, diukur lagi absorbansi bakteri dengan menggunakan spektrofotometer UV-Vis ( $\lambda$ $=600 \mathrm{~nm}$ ). KHM ditentukan dengan membandingkan absorbansi setelah perlakuan inkubasi dikurangi absorbansi sebelum perlakuan. Apabila terdapat konsentrasi terendah yang menghambat pertumbuhan bakteri, ditunjukkan dengan tidak adanya kekeruhan (OD bakteri adalah $\leq 0)$, maka didapatkan Konsentrasi Hambat Minimum (KHM) atau Minimal Inhibitory Concentration (MIC) [17].

\section{Analisis Data}

Data pada penelitian di dapat dengan cara mengukur hasil rata-rata zona hambat di sekitar cakram berisi larutan dari beberapa konsentrasi ekstrak terhadap bakteriStaphylococcus epidermidis.Apabila data yang diperoleh menunjukkan distribusi normal dan homogen, maka digunakan uji parametrik. Pembuktian dilakukan dengan uji ANOVA (Analysis of Variance) satu arah (Two Way). Uji ANOVA dilakukan untuk mengetahui ada atau tidaknya perbedaan pengaruh pemberian larutan uji dari beberapa konsentrasi terhadap efek anti mikroba.Bila ada perbedaan, akan dilanjutkan dengan uji perbandingan berganda menggunakan metode Least Significant Different (LSD) atau Benferoni. Uji LSD dilakukan untuk mengetahui ada atau tidaknya perbedaan pengaruh pemberian larutan uji terhadap efek anti mikroba antar kelompok perlakuan.

\section{HASIL DAN PEMBAHASAN}

Hasil berat ekstrak kental yang diperoleh dari maserasi daun mindi adalah 257.5 gram dan rendemen yang diperoleh $17.16 \%$.

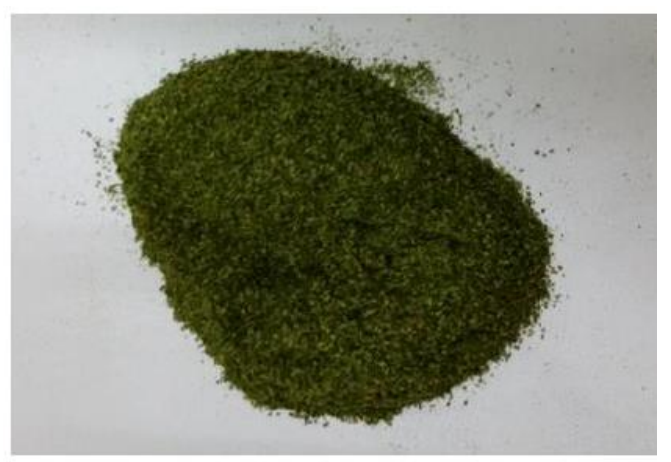

Gambar 1. Simplisia Daun Mindi 


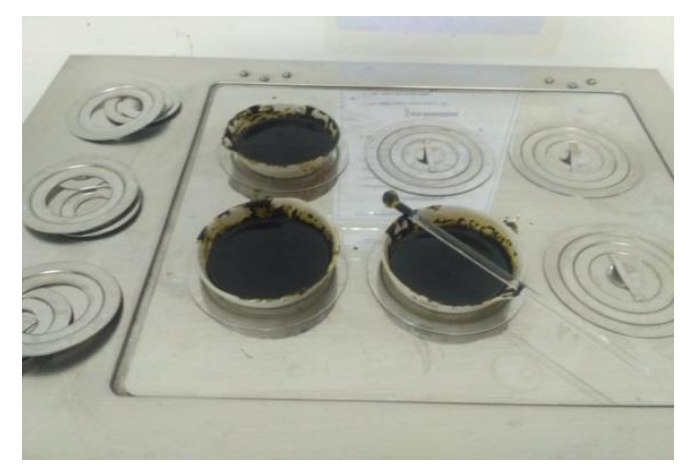

Gambar 2. Ekstrak Daun Mindi.

\section{Skrining Fitokimia}

Ekstrak yang diperoleh kemudian dilakukan uji skrining fitokimia. Hasil skirining fitokimia bahwa ekstrak daun mindi mengandung senyawa metabolit sekunder yang terlihat pada tabel.

Tabel 1. Hasil Skrining Fitokimia

\begin{tabular}{|c|c|c|c|c|}
\hline No & Senyawa & Perlakuan & Persyaratan & Hasil \\
\hline 1 & Alkaloid & $\begin{array}{lrl}-\mathrm{HCl} & 2 & \mathrm{~N}+ \\
\text { Bouchratdat } & \end{array}$ & $\begin{array}{l}\text { - endapan Coklat } \\
\text {-Endapan Coklat } \\
\text { Jingga } \\
\text {-Endapan Putih }\end{array}$ & + \\
\hline 2 & Saponin & $\begin{array}{l}\text { Air dikocok } 10 \text { detik } \\
+\mathrm{HCl} \text { encer }\end{array}$ & $\begin{array}{l}\text { Tinggi busa } 1 \mathrm{~cm} \\
\text { tertarik pada } \\
\text { lapisan alkohol }\end{array}$ & + \\
\hline 3 & Tanin & $\mathrm{FeCl}_{3} 1 \%$ & $\begin{array}{lr}\text { Warna } & \text { biru } \\
\text { kehitaman } & \text { atau } \\
\text { hijau kecoklatan }\end{array}$ & + \\
\hline 4 & Fenolik & $\begin{array}{l}1 \mathrm{ml} \text { kloroform }+10 \\
\text { tetes } \mathrm{FeCl}_{3} 1 \%\end{array}$ & $\begin{array}{l}(+) \quad \text { terbentuk } \\
\text { warna merah }\end{array}$ & + \\
\hline 5 & Flavonoid & $\begin{array}{l}\mathrm{HCl}_{\mathrm{p}}+\text { logam } \mathrm{Mg}+ \\
\text { Amil alkohol }\end{array}$ & $\begin{array}{ll}\text { Warna } & \text { kuning } \\
\text { merah } & \text { tertarik } \\
\text { pada } & \text { lapisan } \\
\text { alkohol } & \\
\end{array}$ & + \\
\hline 6 & Triterpenoid & $\begin{array}{l}\text { Kloroform }+ \text { Asetat } \\
\text { anhidrida }+\mathrm{H}_{2} \mathrm{SO}_{4}\end{array}$ & $\begin{array}{l}\text { Timbul cincin } \\
\text { warna biru merah, } \\
\text { merah muda atau } \\
\text { ungu }\end{array}$ & + \\
\hline 7 & Steroid & $\begin{array}{l}\text { Kloroform }+ \text { Asetat } \\
\text { anhidrida }+\mathrm{H}_{2} \mathrm{SO}_{4}\end{array}$ & $\begin{array}{l}\text { Timbul cincin } \\
\text { warna hijau atau } \\
\text { biru }\end{array}$ & + \\
\hline 8 & Glikosida & $\begin{array}{l}\text { Asam asetat anhidrat } \\
+ \text { asam sulfat } \\
\text { tetes }\end{array}$ & $\begin{array}{l}\text { Timbul warna } \\
\text { biru }\end{array}$ & + \\
\hline
\end{tabular}

Keterangan : $(+)=$ positif terhadap golongan yang diuji 


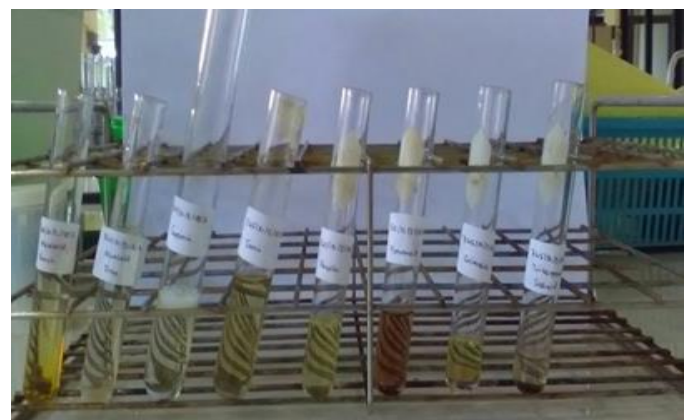

Gambar 3. Hasil Skrining Ekstrak Daun Mindi

Berdasarkan tabel diatas diperoleh hasil skrining fitokimia ekstrak etanol $70 \%$ daun Mindi mengandung senyawa metabolit sekunder antara lain alkaloid, saponin, tanin, fenolik, flavonoid, triterpenoid, steroid, glikosida, sehingga memungkinan senyawa tersebut tidak ikut terektraksi.

\section{Uji Aktivitas Antibakteri}

Pengujian pertama yang dilakukan adalah uji aktivitas antibakteri dengan metode difusi untuk menentukan pada fraksi mana yang mempunyai aktivitas zona hambat yang paling tinggi dan dilakukan 3 kali pengulang (triplo). Dalam penelitian ini kontrol positif yang digunakan adalah klindamisin. Sampel uji yang digunakan adalah fraksi air, n-heksan, dan etil asetat.

Tabel 2. Zona Hambat Fraksi Air Terhadap Staphylococcus epidermidis.

\begin{tabular}{|c|c|c|c|c|}
\hline \multirow{2}{*}{ Konsentrasi } & \multicolumn{3}{|c|}{ Zona hambat (mm) } & \multirow{2}{*}{$\begin{array}{c}\text { Rata-rata } \\
(\mathbf{m m})\end{array}$} \\
\cline { 2 - 4 } & I & II & III & 20.470 \\
\hline Klindamisin & 20.47 & 20.50 & 20.44 & 0 \\
\hline $\mathrm{DMSO}$ & 0 & 0 & 0 & 18.190 \\
\hline $3000 \mu \mathrm{g} / \mathrm{disk}$ & 18.23 & 18.15 & 18.19 & 17.330 \\
\hline $2500 \mu \mathrm{g} / \mathrm{disk}$ & 17.29 & 17.33 & 17.37 & 16.783 \\
\hline $2000 \mu \mathrm{g} / \mathrm{disk}$ & 16.78 & 16.80 & 16.77 & 16.067 \\
\hline $1500 \mu \mathrm{g} / \mathrm{disk}$ & 16.06 & 16.12 & 16.02 & \\
\hline
\end{tabular}

Tabel 3. Zona hambat Fraksi n-Heksan Terhadap Staphylococcus epidermidis

\begin{tabular}{|c|c|c|c|c|}
\hline \multirow{2}{*}{ Konsentrasi } & \multicolumn{3}{|c|}{ Zona hambat (mm) } & \multirow{2}{*}{$\begin{array}{c}\text { Rata-rata } \\
(\mathbf{m m})\end{array}$} \\
\cline { 2 - 4 } & I & II & III & 20.180 \\
\hline Klindamisin & 20.24 & 20.18 & 20.12 & 0 \\
\hline $\mathrm{DMSO}$ & 0 & 0 & 0 & 17.367 \\
\hline $3000 \mu \mathrm{g} / \mathrm{disk}$ & 17.56 & 17.36 & 17.18 & 16.400 \\
\hline $2500 \mu \mathrm{g} / \mathrm{disk}$ & 16.02 & 16.11 & 17.07 & 16.050 \\
\hline $2000 \mu \mathrm{g} / \mathrm{disk}$ & 16.34 & 15.85 & 15.96 & 15.200 \\
\hline $1500 \mu \mathrm{g} / \mathrm{disk}$ & 14.86 & 14.77 & 15.97 & \\
\hline
\end{tabular}

Tabel 4. Zona Hambat Fraksi Etil Asetat Terhadap Staphylococcus epidermidis. 


\begin{tabular}{|c|c|c|c|c|}
\hline \multirow{2}{*}{ Konsentrasi } & \multicolumn{3}{|c|}{ Zona hambat (mm) } & \multirow{2}{*}{$\begin{array}{c}\text { Rata-rata } \\
(\mathbf{m m})\end{array}$} \\
\cline { 2 - 4 } & I & II & III & 20.210 \\
\hline Klindamisin & 20.32 & 20.10 & 20.21 & 0 \\
\hline DMSO & 0 & 0 & 0 & 19.127 \\
\hline $3000 \mu \mathrm{g} / \mathrm{disk}$ & 19.06 & 19.11 & 19.21 & 18.240 \\
\hline $2500 \mu \mathrm{g} / \mathrm{disk}$ & 18.28 & 18.32 & 18.12 & 17.560 \\
\hline $2000 \mu \mathrm{g} / \mathrm{disk}$ & 17.71 & 17.41 & 17.56 & 16.890 \\
\hline $1500 \mu \mathrm{g} / \mathrm{disk}$ & 16.89 & 17.00 & 16.78 & \\
\hline
\end{tabular}

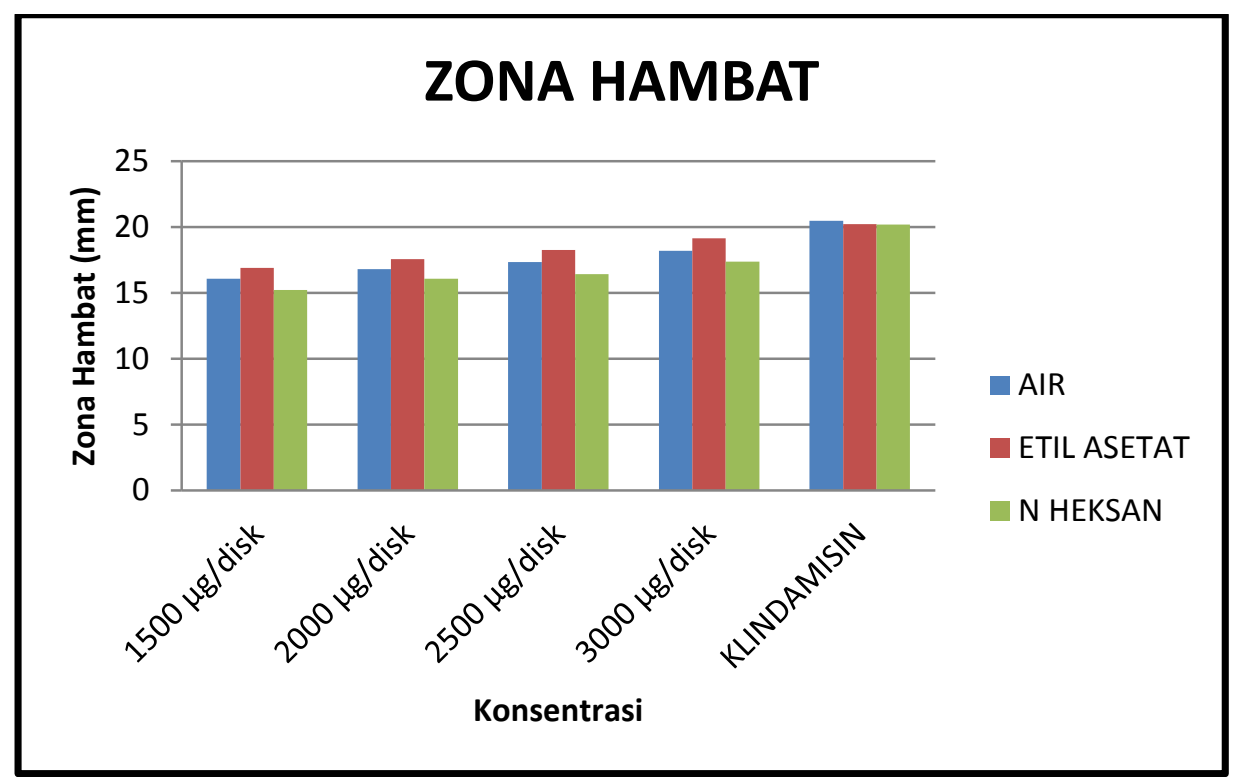

Gambar 4. Grafik Uji Aktivitas Antibakteri Fraksi Daun Mindi TerhadapStaphylococcus epidermidis.

Dari data diatas diperoleh zona hambat pada fraksi etil asetat dengan konsentrasi 1500 $\mu \mathrm{g}$ /disk memiliki daya hambat sebesar 16,89 mm, konsentrasi $2000 \mu \mathrm{g} /$ disk sebesar 17,56 $\mathrm{mm}$, konsentrasi $2500 \mu \mathrm{g} /$ disk sebesar 18,24 mm dan konsentrasi $3000 \mu \mathrm{g} /$ disk sebesar 19,127 mm. Pada fraksi air dengan konsentrasi $1500 \mu \mathrm{g} /$ disk memiliki daya hambat sebesar $16,067 \mathrm{~mm}$, konsentrasi $2000 \mu \mathrm{g} /$ disk sebesar 16,783 mm, konsentrasi $2500 \mu \mathrm{g} /$ disk sebesar 17,330 mm, dan konsentrasi $3000 \mu \mathrm{g} /$ disk sebesar 18,190 mm. Dan pada fraksi n-heksan dengan konsentrasi $1500 \mu \mathrm{g} /$ disk sebesar 15,200 mm, konsentrasi $2000 \mu \mathrm{g} /$ disk sebesar $16,050 \mathrm{~mm}$, konsentrasi $2500 \mu \mathrm{g} /$ disk sebesar 16,400 mm dan konsentrasi $3000 \mu \mathrm{g} /$ disk sebesar $17,367 \mathrm{~mm}$.

Dari data diatas diperoleh zona hambat dari tiap fraksi air, n-heksan dan etil asetat dengan variasi konsentrasi $1500 \mu \mathrm{g} /$ disk, $2000 \mu \mathrm{g} / \mathrm{disk}, 2500 \mu \mathrm{g} / \mathrm{disk}, 3000 \mu \mathrm{g} / \mathrm{disk}$. Dari tiap-tiap fraksi yang memiliki zona hambat terbesar berturut-turut adalah fraksi etil asetat, fraksi air, fraksi n-heksan. Hal ini dikarenakan pada fraksi etil asetat terkandung senyawa flavonoid yang memiliki aktivitas sebagai antibakteri karena kemampuannya membentuk senyawa kompleks dengan protein ekstraseluler dan terlarut sehingga dapat merusak membrane sel bakteri.

Dan diikuti dengan keluarnya senyawa intraseluler[18], senyawa saponin sebagái 
antibakteri dengan cara menurunkan tegangan permukaan sehingga mengakibatkan naiknya permeabilitas atau kebocoran sel dan mengakibatkan senyawa intraseluler akan keluar[19].Dalam pengujian zona hambat dilakukan dengan tujuan untuk melihat kemampuan ekstrak daun mindi sebagai bakteriosida.

Dari hasil pengujian aktivitas antibakteri ekstrak etanol $70 \%$ daun mindi yang didapatkan selanjutnya diujikan dengan menggunakan SPSS (Statistical Package for the Sosial Sciene) for Windows 22.0. Untuk uji KBM menggunakan analisis TWO WAY ANOVA. Terlebih dahulu data pengukuran yang didapatkan dilakukan uji normalitas dan uji homogenitas. Dalam uji normalitas diperoleh nilai $\mathrm{P}>0.05$ yang menunjukkan data terdistribusi normal dan dalam uji homogenitas diperoleh nilai $\mathrm{P} 0.105>0.05$ yang menunjukkan data memiliki varian yang sama. Dikarenakan data terdistribusi normal dan memiliki varian yang sama sehingga dilakukan uji parametrik yaitu TWO WAY ANOVA dan kemudian akan dilakukan uji lanjutan berupa uji post hoc yang bertujuan untuk melihat perbandingan zona hambat antar tiap konsentrasi.

\section{Penentuan Konsentrasi Hambat Minimum (KHM)}

Penentuan KHM dilakukan dengan metode dilusi cair Kirby and Bauer menggunakan media cair Mueller Hinton Broth (MHB) dan diukur absorbansi drengan spektrofotometer UV-Vis sebelum dan sesudah inkubasi untuk melihat pertumbuhan bakteri uji setelah perlakuan.

Tabel 5. Hasil Dari Uji Konsentrasi Hambat Minimum (KHM) pada Fraksi Etil Asetat

\begin{tabular}{|c|c|c|}
\hline Konsentrasi & Absorbansi Awal & Absorbansi Akhir \\
\hline $10.000 \mathrm{ppm}$ & 0.144 & 0.250 \\
$10.000 \mathrm{ppm}$ & 0.160 & 0.262 \\
$10.000 \mathrm{ppm}$ & 0.167 & 0.270 \\
\hline $30.000 \mathrm{ppm}$ & 0.162 & 0.228 \\
$30.000 \mathrm{ppm}$ & 0.168 & 0.241 \\
$30.000 \mathrm{ppm}$ & 0.159 & 0.235 \\
& & 0.219 \\
\hline $50.000 \mathrm{ppm}$ & 0.143 & 0.221 \\
$50.000 \mathrm{ppm}$ & 0.150 & 0.215 \\
$50.000 \mathrm{ppm}$ & 0.158 & 0.216 \\
\hline $70.000 \mathrm{ppm}$ & 0.160 & 0.223 \\
$70.000 \mathrm{ppm}$ & 0.145 & 0.210 \\
\hline $70.000 \mathrm{ppm}$ & 0.157 & \\
\hline
\end{tabular}




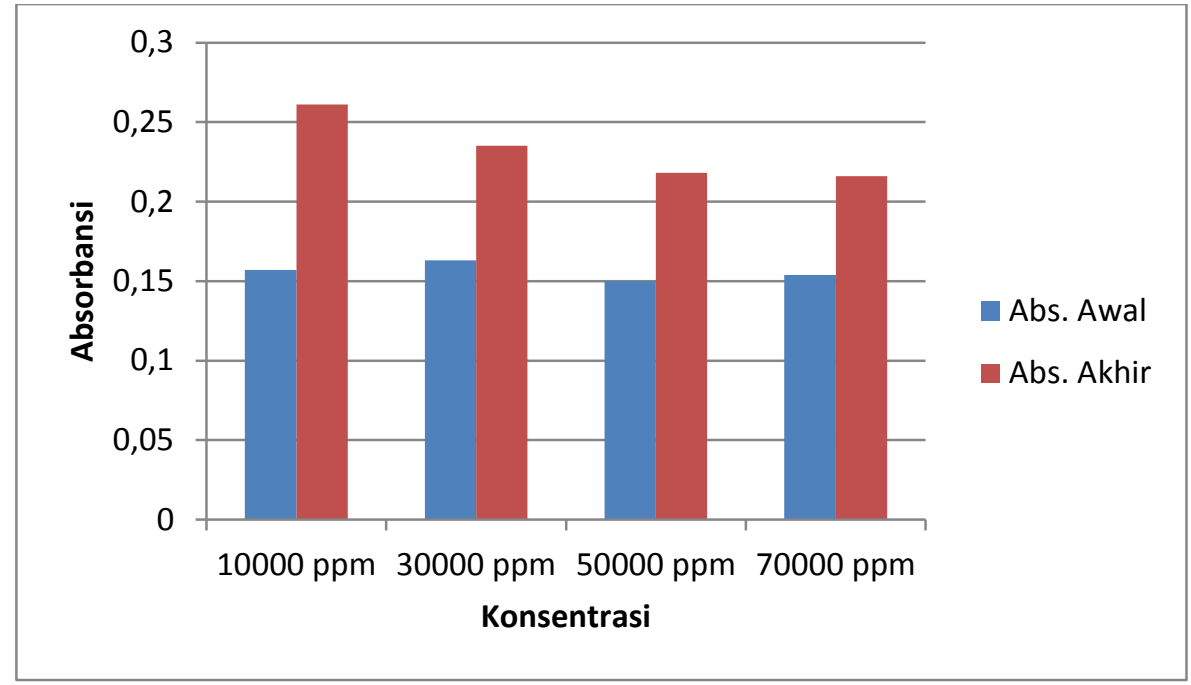

Gambar 2. Grafik Uji Konsentrasi Hambat Minimum Fraksi Etil Asetat Daun Mindi Terhadap Staphylococcus epidermidis

Dari hasil data diatas dapat dilihat dari kekeruhan yang terjadi pada larutan dan konsentrasi yang digunakan untuk uji KHM diambil dari konsentrasi terendah yaitu fraksi etil asetat pada konsentrasi $1.5 \mu \mathrm{g} /$ disk dengan diameter zona hambat rata-rata $16.890 \mathrm{~mm}$. maka dapat diketahui bahwa hasil uji kadar hambat minimum dari fraksi etil asetat dari daun Mindi terhadap pertumbuhan bakteri Staphylococcus epidermidis adalah 50.000 ppm sampai $70.000 \mathrm{ppm}$. Berdasarkan hasil analisis menggunakan SPSS dengan uji ONE WAY ANOVA diperoleh nilai $\mathrm{P}$ yaitu $0.000(<0.05)$ yang menunjukan terdapat perbedaan yang signifikan antar tiap konsentrasi terhadap pertumbuhan bakteri Staphylococcus epidermidis, namun pada konsentrasi $50.000 \mathrm{ppm}$ dan $70.000 \mathrm{ppm}$ diperoleh nilai p $0.735(>0.05)$ yang menunjukan tidak terdapat perbedaan yang signifikan dalam pertumbuhan bakteri Staphylococcus epidermidis sehingga konsentrasi 50.000 ppm merupakan konsentrasi minimum yang dapat menghambat pertumbuhan Staphylococcus epidermidisdan pada konsentrasi terendah yang dapatmenghambat pertumbuhan bakterimaka ditunjukkan dengan tidak adanya kekeruhan[17].

\section{KESIMPULAN}

Berdasarkann dari hasil penelitian yang dilakukan dapat disimpulkan bahwa Aktivitas antibakteri ekstrak daun mindi tertinggi yaitu terdapat pada fraksi etil asetat yang memiliki daya hambat paling besar dibandingkan dengan fraksi N-heksan dan fraksi Air dan uji Konsentrasi Hambat Minimum (KHM) pada fraksi etil asetat terdapat konsentrasi terendah yang dapat menghambat pertumbuhan bakteri Staphylococcus epidermidis yaitu pada konsentrasi 50.000 ppm. 


\section{DAFTAR RUJUKAN}

1. Jankovic, S., et al, Quality of Life Among School Children with Acne:Results of a Crosssectional Study, Indian J Dermatol, 2012;(78):454-458.

2. Harahap, Marwali., Ilmu Penyakit Kulit, Hipokrates: Jakarta.ITB, Bandung; 2000.

3. Madani, A. Perbandingan aktivitas dan mekanisme penghambatan antibakteri ekstrak air dengan ekstrak etil asetat gambir (Uncaria gambir Roxb.) Terhadap bakteri staphylococcus Epidermidis, Staphylococcus mutans dan staphylococcus pyogenes. Skripsi, Universitas Islam Negeri, Jakarta; 2010.

4. Ara, K., dkk, Foot Odor Due To Microbial Metabolisme And Its Control, Can. J.Microbiol.,2006;(52), 357-364.

5. Nurfadilah. Uji Bioaktifitas antibakteri Ekstrak dan Fraksi Lamun dari Kepulauan Spermonde, Kota Makassar. Skripsi. Jurusan Ilmu Kelautan, Fakultas Ilmu Kelautan dan Perikanan, Universitas Hasanuddin, Makassar;2003.

6. Sharma, D. a. Y. P. Preliminary and Pharmacological Profile of Melia azedarach L : An Overview. Journal of Applied Pharmaceutical Science, 2013;3(12): 133-138.

7. Azam, M. M., et al,Pharmacological Potentials of Melia azedarach L. -A review. American journal of bioscience, 2013;(1): 44-49.

8. Asadujjaman, e. a. Assessment of bioactivities of Ethanolic Extract of Melia azedarach (Meliaceae) Leaves. Journal of Coastal Life Medicine,2013;(1): 118-122.

9. Ahmed, M. F., et al, Phytochemical Studies and Antioxidant activity of Melia azedarach Linn leaves by DPPH Scavenging Assay. Journal of Pharmaceutical Applications, 2013;(1): 271276

10. Manu, K. R. Sterilisasi, Teknik Aseptik Laboratorium, Media pertumbuhan Bakteri Dan Isolasi Bakteri. Laporan Praktikum Bakteriologi Dan Mikrobiologi. Fakultas Kedokteran Hewan. Universitas Nusa Cendana. Kupang; 2013

11. Harborne, J.B., Metode Fitokimia Cetakan Keempat Diterjemahkan Oleh Kokasih Padmawinata dan Iwang Sudiro, Terbitan II, Penerbit; 2006.

12. Harborne, J.B.,Metode Fitokimia, Penuntun Modern Analisa Tumbuhan, Diterjemahkan Oleh Kokasih Padmawinata dan Iwang Sudiro, Terbitan II, Penerbit ITB, Bandung; 1987.

13. Simanjuntak, M.R.,Ekstraksi dan Fraksinasi Komponen Ekstrak Daun Tumbuhan Senduduk (Melastoma malabathricum .L) Serta Pengujian Efek Sediaan Krim Terhadap Penyembuhan Luka Bakar, Skripsi, Universitas Sumatra Utara, Medan; 2008

14. Noverita, D.F., et al, Isolasi dan Uji Aktivtas Antibakteri Jamur Endofit Dari Daun dan Rimpang Zingiber ottensii Vol,Jurnal Farmasi Indonesia. 2009;(4): 171-176Sharma, D. a. Y. P. Preliminary and Pharmacological Profile of Melia azedarach L :An Overview. Journal of Applied Pharmaceutical Science, 2013;3(12):133-138.

15. Suriawiria, U.,Mikrobiologi Dasar, Papas Sinar Sinanti, Jakarta; 2005.49.

16. Azis. Syaikhul,Uji Aktivitas Antibakteri Ekstrak Etanol Daun Dan Umbi Bakung Putih (Crinum asiaticum L.) Terhadap Bakteri Penyebab Jerawat. Skripsi, Program Studi Farmasi. Fakultas Kedokteran dan Ilmu Kesehatan, Universitas Negeri Islam Syarif Hidayatullah, Jakarta; 2010.

17. Fatisa, Y. Daya Antibakteri Ekstrak Kulit dan Biji Buah Pulasan (Nephelium mutabile) Terhadap Staphylococcus aureus dan Escherichia coli secara in vitro. Jurnal Peternakan Vol 10 no 1 Februari 2013 (31-38), Universitas Islam Negeri Syarif Kasim Riau; 2013

18. Mercy Ngajow, Jemmy Abidjulu, Vanda S. Kamu.Pengaruh Antibakteri Ekstrak Kulit Batang Matoa (Pometia pinnata) terhadap Bakteri Staphylococcus aureus secara In vitro, Jurusan Kimia, FMIPA, Jurnal MIPA Unsrat Online, Unsrat, Manado.2013;2(2): 128-132

19. Nuria, M.C., A. Faizatun., dan Sumantri. Uji Antibakteri Ekstrak Etanol Daun Jarak Pagar (Jatropha cuircas L) terhadap Bakteri Staphylococcus aureus ATCC 25923, Escherichia coli ATCC 25922, dan Salmonella typhi ATCC 1408. Jurnal Ilmu - ilmu Pertanian. 2009;5: 26 37. 